\title{
Thrombocytopenia in critically ill patients due to vascular microthrombotic disease: pathogenesis based on "two activation theory of the endothelium"
}

\author{
Jae C. Chang* \\ Department of Medicine, University of California Irvine School of Medicine, Irvine, California, USA
}

\begin{abstract}
The pathogenesis of thrombocytopenia in critically ill patients (TCIP) has not been established yet. Based on "two-activation theory of the endothelium", TCIP is a manifestation of platelet activation and consumption in association with endotheliopathy. Endotheliopathy occurs in many critical illnesses. An injury to vascular endothelial cells (ECs) from pathogen or insult leads to endothelial dysfunction, which initiates the activation of two distinctly independent molecular pathways (i.e., inflammatory and microthrombotic). The activation of inflammatory pathway occurs due to the release of inflammatory cytokines from injured ECs. Inflammatory cytokines mediate inflammation. The activation of microthrombotic pathway is induced by the activation of platelets and endothelial exocytosis of unusually large von Willebrand factor multimers (ULVWF). Activated platelets are recruited by exocytosed ULVWF, which are anchored to ECs, and together assemble microthrombi consisting of platelet-ULVWF complexes. This microthrombogenesis leads to consumptive thrombocytopenia (i.e., TCIP) and disseminated intravascular microthrombosis (DIT). DIT triggers vascular microthrombotic disease (VMTD), which manifestations include hypoxic multi-organ dysfunction syndrome, and thrombotic microangiopathy (TMA). The combined syndrome due to the activation of both inflammatory pathway and microthrombotiic pathway is called systemic inflammatory response syndrome (SIRS). Also, the true nature of "DIC" is endotheliopathy-associated DIT/VMTD (i.e., TTP-like syndrome).
\end{abstract}

\begin{abstract}
Abbreviations
ADAMTS13: a disintegrin and metalloproteinase with a thrombospondin type 1 motif, member 13, rADAMTS13: recombinant ADAMTS13, AH/AHNS: acute hepatitis/acute hepatic necrosis syndrome, ARDS: acute respiratory distress syndrome, ARF: acute renal failure, CABG: coronary artery bypass graft, C-APLAS: catastrophic anti-phospholipid antibody syndrome, CNS: central nervous system, CNSD: central nervous system dysfunction, DSS: dengue shock syndrome, DIC: disseminated intravascular coagulation, DIT: disseminated intravascular thrombosis, ECs: endothelial cells, GE: gastroenteritis, HC: hepatic coagulopathy, HCP: hantavirus pulmonary syndrome, HCPS: hantavirus cardio-pulmonary syndrome, HELLPs: hemolysis: elevated liver enzymes: and low platelet count syndrome, HFRS: hemorrhagic fever with renal syndrome, HUS: hemolytic-uremic syndrome, LDH: lactate dehydrogenase, MAHA: microangiopathic hemolytic anemia, aMAHA: atypical microangiopathic hemolytic anemia, MERS-CoV: middle east respiratory syndrome-coronavirus, MODS: multi-organ dysfunction syndrome, MOF: multi-organ failure, MRSA: methicillin-resistant staphylococcus aureus, NOMI: non-occlusive mesenteric ischemia, RMSF: Rocky mountain spotted fever, SARS-CoV: severe acute respiratory syndrome-coronavirus, SIRS: systemic inflammatory response syndrome, SFTS: severe fever with thrombocytopenia syndrome, TAMOF: thrombocytopeniaassociated multiple organ failure, TCIP: thrombocytopenia in critically ill patients, TMA: thrombotic microangiopathy, TTP: thrombotic thrombocytopenic purpura, ULVWF: unusually large von Willebrand factor multimers, VMTD: vascular microthrombotic disease
\end{abstract}

\section{Introduction}

In the critically ill patient, thrombocytopenia is a very common hematological condition that occurs due to several different pathogenic mechanisms, and manifests with a broad clinical spectrum from benign presentation to life-threatening emergency. Mild to moderate thrombocytopenia plays a minor role in short-term clinical course, but the patient outcome related to the thrombocytopenia depends more upon the underlying pathologic disease.

Even after careful exclusion of the known etiology of thrombocytopenia, the cause of thrombocytopenia cannot be clearly determined in more than half of critically ill patients. This etiology-unidentified thrombocytopenia, encountered in critical illnesses (e.g., sepsis/septic shock, severe trauma, and complications of pregnancy, transplant and surgery), has been designated as "thrombocytopenia in critically ill patients" (TCIP) [1]. TCIP is now suspected to be an unfavorable indicator influencing the prognosis of the patient [2-4].

Correspondence to: Jae C. Chang, MD, Department of Medicine, University of California Irvine School of Medicine, Irvine, California, USA, Tel: 949-3872207; E-mail: jaec@uci.edu

Key words: thrombocytopenia, endotheliopathy, thrombotic thrombocytopenic purpura (TTP), TTP-like syndrome, therapeutic plasma exchange, disseminated intravascular coagulation (DIC), disseminated intravascular microthrombosis, vascular microthrombotic disease (VMTD), microthrombogenesis

Received: June 07, 2017; Accepted: June 27, 2017; Published: June 30, 2017 


\section{TCIP in the critical care setting}

The known mechanisms producing thrombocytopenia in critically ill patients include: 1) decreased production of the platelet due to transient bone marrow suppression or myelodysplasia (e.g., infection-associated), 2) increased destruction due to immune or nonimmune response (e.g., drug or transfusion-induced), 3) increased utilization (e.g., disseminated intravascular coagulation - DIC), 4) increased consumption (e.g., heparin-induced thrombocytopenia, and thrombotic thrombocytopenic purpura - TTP), and 5) sequestration secondary to hypersplenism $[5,6]$. To date, TCIP is the term to use after the exclusion of known mechanisms.

The example of critical illnesses and conditions associated with TICP is listed in Table 1. Thrombocytopenia is typically recognized after admission to the critical care unit for conditions such as sepsis, severe physical injury, acute respiratory distress syndrome (ARDS), and central nervous system dysfunction. In severe infection due to pathogen causing bacterial sepsis, viral pneumonia (e.g., Middle East respiratory distress syndrome due to coronavirus), and viral hemorrhagic fevers (e.g., Ebola, hantavirus, and dengue), TCIP occurs in advancing stage of the illness.

TCIP is mild to moderately severe usually with the platelet count not less than 20,000/ $\mu \mathrm{L}$. Hemorrhagic tendency has been uncommon unless it occurs with severe thrombocytopenia, DIC or hepatic coagulopathy. Thus, to some clinicians TCIP is considered to be not a serious issue in the management of critically ill patients.

The degree of thrombocytopenia has been correlated with the severity of clinical course. Increasing thrombocytopenia was associated with higher mortality and longer length of hospital stay, and the increase of the platelet count was an early sign of clinical improvement [2-4,6-10]. Severe thrombocytopenia commonly has occurred in association with progressive multi-organ dysfunction syndrome (MODS) $[4,11,12]$ and systemic inflammatory response syndrome (SIRS) $[13,14]$. These observations support TCIP is an important participant in the pathogenesis of the critical illness.

\section{Endothelium and critical illnesses}

The endothelium is a delicate biological structure that lines the entire circulatory system. It maintains the integrity of the blood supply by protecting the human body from the invasion of pathogen and insult. It also guards the circulatory system against unneeded intravascular coagulation by preventing the intrusion of tissue factor (TF) at the basement membrane of ECs [15]. ECs do not express in vivo TF. In sepsis and other critical illnesses, the membrane barrier of ECs is not disrupted. Thus, TF does not enter into circulation from extravascular compartment, and intravascular coagulation (i.e., DIC) cannot be initiated. However, injured ECs become activated, and endothelial dysfunction leads to endotheliopathy triggering several molecular responses [16-22].

Endotheliopathy is associated with inflammation [23], platelet activation [24] and exocytosis of unusually large von Willebrand factor multimers (ULVWF) [25-27]. It is also associated with thrombocytopenia (i.e., TCIP) and disseminated intravascular microthrombosis (DIT) $[28,29]$. Other clinical syndromes associated with critical illnesses include SIRS [13,14], ARDS [19,22], MODS [4,6,11,12,14], “DIC" [30-32], thrombotic thrombocytopenic purpura (TTP)-like syndrome [33-39], hepatic coagulopathy, and others [36,40].

Current hypothesis for the pathogenesis of vascular microthrombosis, especially in sepsis, is based on the intricate interaction between inflammation and coagulation system. The release of endothelial cytokines would trigger TF-mediated activation of coagulation leading to disseminated intravascular micro blood clots, inducing to vascular microthrombosis (i.e., "DIC") [30,41,42].

Table 1. Examples of thrombocytopenia (TCIP)-associated conditions seen in critical care.

\begin{tabular}{|c|c|c|c|}
\hline & Causes & Involved organs & Associated syndromes \\
\hline $\begin{array}{l}\text { Infectious agent } \\
\quad \text { Virus }\end{array}$ & $\begin{array}{l}\text { Ebola } \\
\text { H1N1 influenza } \\
\text { MERS-CoV } \\
\text { SARS-CoV } \\
\text { Hantavirus } \\
\text { Dengue } \\
\text { SFTS virus }\end{array}$ & $\begin{array}{l}\text { Lungs; liver; multi-organs } \\
\text { Brain; lungs; multi-organs } \\
\text { Lungs; multi-organs } \\
\text { Lungs; multi-organs } \\
\text { Heart; lung; kidneys } \\
\text { Adrenals; multi-organs } \\
\text { Multi-organs }\end{array}$ & $\begin{array}{l}\text { ARDS; hepatic necrosis; MODS } \\
\text { Encephalopathy; ARDS; MODS } \\
\text { ARDS; MODS } \\
\text { ARDS; MODS } \\
\text { HCPS; HPS; HFRS } \\
\text { DSS; MODS } \\
\text { SFTS; MODS }\end{array}$ \\
\hline Bacteria & $\begin{array}{l}\text { Neisseria meningitides } \\
\text { E.Coli O157:H7 } \\
\text { MRSA } \\
\text { Klebsiella pneumonia } \\
\text { Various bacterial sepsis }\end{array}$ & $\begin{array}{l}\text { Adrenals } \\
\text { Bowels; kidneys } \\
\text { Multi-organs } \\
\text { Lungs; multi-organs } \\
\text { Lungs; multi-organs } \\
\end{array}$ & $\begin{array}{l}\text { Waterhouse-Friderichsen syndrome } \\
\text { Hemolytic-uremic syndromes; GE } \\
\text { MODS; SIRS } \\
\text { ARDS; MODS; SIRS } \\
\text { ARDS; MODS; SIRS; TAMOF; C-APLAS }\end{array}$ \\
\hline Rickettsia & Rickettsia rickettsii & Skin; multi-organs & RMSF; MODS \\
\hline Fungus & Candida albicans & Multi-organs & MODS; SIRS \\
\hline Parasite & $\begin{array}{l}\text { Plasmodium falciparum } \\
\text { Plasmodium vivax }\end{array}$ & $\begin{array}{l}\text { Brain; multi-organs } \\
\text { Lungs; multi-organs }\end{array}$ & $\begin{array}{l}\text { Cerebral malaria; MODS; ARDS; SIRS } \\
\text { ARDS }\end{array}$ \\
\hline $\begin{array}{l}\text { Trauma } \\
\text { Lungs/chest trauma } \\
\text { CNS trauma }\end{array}$ & $\begin{array}{l}\text { Motorcycle accident } \\
\text { Head injury }\end{array}$ & $\begin{array}{l}\text { Lungs; multi-organs } \\
\text { Brain; lungs; multi-organs }\end{array}$ & $\begin{array}{l}\text { ARDS; MODS; SIRS } \\
\text { Encephalopathy; ARDS; MODS; SIRS }\end{array}$ \\
\hline $\begin{array}{l}\text { Surgery } \\
\text { Cardiac surgery } \\
\text { Vascular surgery } \\
\text { Bowel surgery }\end{array}$ & $\begin{array}{l}\text { CABG; open heart surgery } \\
\text { Aortic aneurysm surgery } \\
\text { Mesenteric inflammation }\end{array}$ & $\begin{array}{l}\text { Lungs; heart; multi-organs } \\
\text { Lungs; multi-organs } \\
\text { Mesentery; multi-organs }\end{array}$ & $\begin{array}{l}\text { ARDS; myocardial ischemia; MODS } \\
\text { ARDS; MODS } \\
\text { NOMI; MODS }\end{array}$ \\
\hline $\begin{array}{l}\text { Pregnancy } \\
\quad \text { Preeclampsia }\end{array}$ & Toxin (?); infection (?) & Lungs; uterus; multi-organs & ARDS; HELLPs; Abruptio placenta; MODS \\
\hline $\begin{array}{l}\text { Transplant } \\
\text { Liver transplant } \\
\text { Kidney transplant }\end{array}$ & $\begin{array}{l}\text { Infection (?) } \\
\text { Infection (?) }\end{array}$ & $\begin{array}{l}\text { Lungs; multi-organs } \\
\text { Lungs; multi-organs }\end{array}$ & $\begin{array}{l}\text { ARDS; MODS } \\
\text { ARDS: MODS }\end{array}$ \\
\hline
\end{tabular}


Contrary to this concept, microthrombogenesis plays a key role in the pathogenesis of TTP and TTP-like syndrome. In endotheliopathy, the platelet is activated and excessive amounts of ULVWF are released from ECs [24-27,40]. The result is the formation of microthrombi made of platelet-ULVWF complexes, which also lead to vascular microthrombosis $[26,27,34,36,40]$.

To annotate inflammation and circulatory disorder in the critical illness, a novel hypothesis of "two-activation theory of the endothelium" is proposed $[36,40]$.

\section{Two-activation theory of the endothelium}

Endotheliopathy initiates two significant molecular events: 1) release of inflammatory cytokines (e.g., interleukin (IL)-1, IL-6, tumor necrosis factor- $\alpha$, and others) [16-22], and 2) activation of the platelet and exocytosis of ULVWF [24-27]. The former triggers inflammation, which is called "activation of inflammatory pathway", and the latter initiates microthrombogenesis, which is expressed as "activation of microthrombotic pathway". These two independent responses are the essence of "two-activation theory of the endothelium" as illustrated in Figure 1. The manifestation of activated inflammatory pathway is inflammation with symptoms such as fever, myalgia, arthralgia, and malaise, and that of activated microthrombotic pathway is consumptive thrombocytopenia, hypoxemia, multi-organ dysfunction and multiple clinical syndromes as presented in Figure 1 and Table 1.

The activation of inflammatory pathway occurs due to release of cytokines in both sepsis and non-septic critical illnesses. Unlike in nonseptic illnesses, sepsis also promotes inflammation through another loop of activated circulating immune cell pathway (e.g., macrophages, monocytes, neutrophils, and lymphocytes). This pathway also interacts with activated ECs as shown in Figure $1[43,44]$. This additional cytokine expression accentuates the inflammatory pathway that could result in "cytokine storm". This mechanism explains why severer inflammation occurs in sepsis, which might lead to SIRS $[11,13,14,45]$.

On the other hand, the activation of microthrombotic pathway is initiated by activated platelets and excessively exocytosed ULVWF that are anchored to ECs as long elongated strings [46,47]. If protease ADAMTS13, which cleaves ULVWF to smaller molecular weight VWF, is under expressed [36,48], activated platelets under shear stress of blood flow are recruited to the uncleaved ULVWF strings. This microthrombogenesis generates intravascular microthrombi consisting of platelet-ULVWF complexes at ECs [46,47]. This process sets off DIT and could lead to multiple clinical syndromes.

\section{Endotheliopathy-associated vascular microthrombotic disease}

DIT is the underlying pathology provoking vascular microthrombotic disease (VMTD) [36,40], which triggers hypoxic multi-organ dysfunction and thrombotic microangiopathy (TMA). Three kinds of disseminated VMTD are known to exist: 1) antibodyassociated VMTD (i.e., acquired TTP), 2) gene mutation-associated VMTD (i.e., hereditary TTP), and 3) endotheliopathy-associated VMTD (TTP-like syndrome). Endotheliopathy-associated DIT/VMTD is the underlying pathologic condition producing TTP-like syndrome. It is characterized by TCIP, microangiopathic hemolytic anemia (MAHA)/ atypical MAHA (if fewer schistocytes are present)with/without MODS.

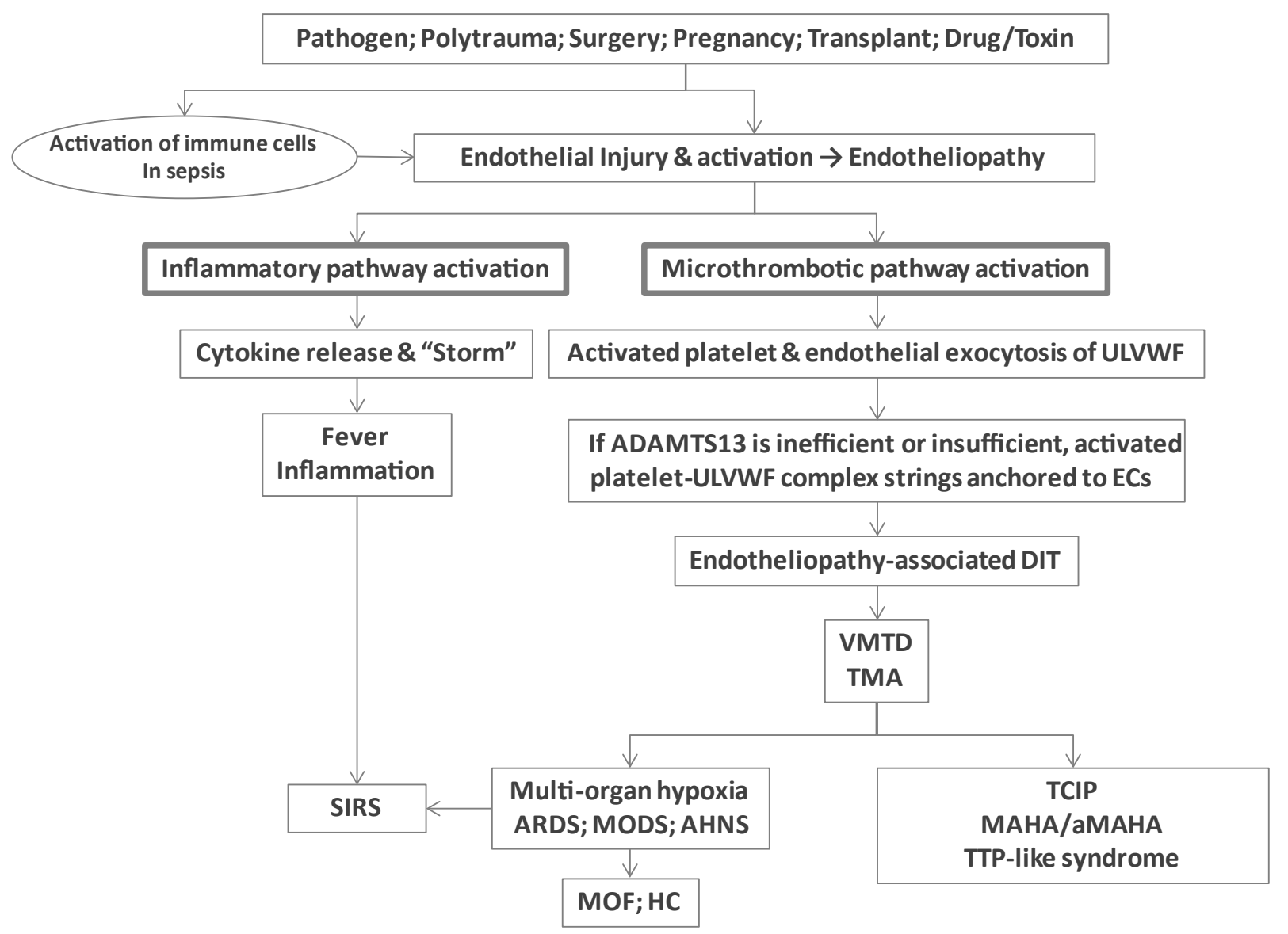

Figure 1. Pathogenesis of TCIP and related syndromes in critically ill patients 
Perhaps the dissimilar clinical features (e.g., central nervous system dysfunction in TTP and ARDS in TTP-like syndrome) are related to microthrombogenesis occurring at different sites, resulting in different clinical syndromes due to divergent localization of intravascular microthrombi, even among the TTP-like syndromes (Table 2). TTP seems to be the result of microvascular microthrombosis, but TTP-like syndrome is the result of vascular microthrombosis. In the former, microthrombogenesis occurs in the circulation and formed microthrombi become lodged in microvasculatures [49], predominantly in the brain and kidneys. But in the latter, it occurs at ECs-anchored long elongated ULVWF strings $[46,47]$ in smaller and larger vasculatures, commonly involving the lungs (i.e., ARDS), kidneys (i.e., acute renal failure, hemolytic-uremic syndrome), liver (i.e., acute hepatic necrosis syndrome), intestines (i.e., gastroenteritis), pancreas (i.e., acute pancreatitis), muscles (i.e., rhabdomyolysis), heart (i.e., acute myocardial ischemia), skin (i.e., purpura fulminans), and others.

\section{“DIC" vs. DIT}

According to the "two-activation theory", DIT induced by microthrombogenesis is completely different from true DIC occurring as a result of activated TF coagulation pathway. DIT is a microthrombotic disorder, but true DIC is a coagulation disorder. Additionally, the current concept of pathologic coagulation (i.e., "DIC") through TF pathway in the critical illness cannot be correct because in vivo sufficient $\mathrm{TF}$ is not available in the ECs. The characteristic difference between DIT and true DIC is shown in Table 3.

Donald McKay in early 1950s coined the term "DIC" [50] for a coagulation disorder that is caused by abnormally activated intravascular thrombotic state. $\mathrm{He}$ and his associates believed intravascular microthrombi in the luminal arterioles and capillaries in the pathologic tissue examination were micro blood clots made of platelets, coagulation factors and fibrins. His followers also supported the diagnosis of "DIC" with the laboratory result of prolonged prothrombin time and activated partial thromboplastin time, hypofibrinogenemia, and increased fibrin degradation products. The most of the coagulopathy associated with thrombocytopenia in the critical illnesses has been ascribed to "DIC" [51-53].

It should be emphasized that since no single laboratory test or set of tests is sensitive or specific enough to allow a definite diagnosis of

Table 2. Genesis and characteristics of DIT/VMTD in TTP and TTP-like syndrome.

\begin{tabular}{|c|c|c|}
\hline & $\begin{array}{l}\text { ADAMTS13 gene mutation-associated VMTD (Hereditary } \\
\text { TTP) ADAMTS13 antibody-associated VMTD (Acquired } \\
\text { TTP) }\end{array}$ & Endotheliopathy-associated VMTD (TTP-like syndrome) \\
\hline Secondary event & $\begin{array}{l}\text { Excessive circulating ULVWF \& platelet aggregation } \\
\downarrow \\
\text { Microthrombogenesis leading to platelet-ULVWF complexes } \\
\downarrow\end{array}$ & $\begin{array}{l}\text { Sepsis/septic shock due to pathogens (e.g., viruses; bacteria; fungi; rickettsia; parasites) } \\
\text { Polytrauma (e.g., chest/lungs; bones; skull/brain injury) } \\
\text { Pregnancy complications (e.g., preeclampsia; abruptio placenta; amniotic fluid } \\
\text { embolism) } \\
\text { Cancer (e.g., stomach; breast; lung) } \\
\text { Transplant (e.g., liver; kidney; bone marrow) } \\
\text { Drug and chemical (e.g., cyclosporine; mytomycin C; Shiga toxin; ricin) } \\
\quad \downarrow \\
\text { Endothelial injury \& platelet activation } \rightarrow \text { ECs activation \& endotheliopathy } \\
\quad \downarrow \\
\text { Cytokine release and cytokine storm } \rightarrow \text { Inflammation } \rightarrow \text { SIRS } \\
\text { Endothelial exocytosis of ULVWF \& anchored to ECs as a long elongated strings } \rightarrow \\
\text { DIT }\end{array}$ \\
\hline Tertiary event & $\begin{array}{c}\text { Microthrombi lodged in arteriolar capillary lumens } \\
\downarrow \\
\text { VMTD } \\
\downarrow \\
\text { TMA (microthrombotic microangiopathy) } \\
\downarrow \\
\text { TTP }\end{array}$ & $\begin{array}{c}\downarrow \\
\text { Vascular microthrombogenesis leading to platelet-ULVWF complexes anchored to ECs } \\
\downarrow \\
\text { VMTD } \\
\downarrow \\
\text { TMA (microthrombotic angiopathy) } \\
\downarrow \\
\text { TTP-like syndrome }\end{array}$ \\
\hline $\begin{array}{l}\text { Hematologic features } \\
\text { Platelet } \\
\text { Red blood cell } \\
\text { Clinical syndromes } \\
\text { Inflammation/fever } \\
\text { Cytokine storm } \\
\text { SIRS } \\
\text { CNSD } \\
\text { ARDS } \\
\text { GE } \\
\text { AH/AHNS } \\
\text { ARF/HUS } \\
\text { Hepatic coagulopathy } \\
\text { DIC*(see text) }\end{array}$ & $\begin{array}{l}\text { Consumptive thrombocytopenia } \\
\text { MAHA } \\
\text { Fever may be present (?) } \\
\text { Absent } \\
\text { Absent } \\
\text { Very common } \\
\text { Absent } \\
\text { Uncommon } \\
\text { Uncommon } \\
\text { Very common } \\
\text { Not reported } \\
\text { Doesn't occur }\end{array}$ & $\begin{array}{l}\text { Consumptive thrombocytopenia } \\
\text { MAHA/aMAHA } \\
\text { Very common } \\
\text { Often present in sepsis/septic shock } \\
\text { Often present in sepsis/septic shock } \\
\text { Common } \\
\text { Very common } \\
\text { Common } \\
\text { Common } \\
\text { Common } \\
\text { Common } \\
\text { Doesn't occur }\end{array}$ \\
\hline $\begin{array}{l}\text { Laboratory features } \\
\text { ADAMTS13 activity } \\
\text { ADAMTS13 antibody } \\
\text { LDH } \\
\text { Haptoglobin } \\
\text { Schistocytosis } \\
\end{array}$ & $\begin{array}{l}\text { Markedly decreased }(<5 \% \text { of normal }) \\
\text { Positive in acquired TTP } \\
\text { Increased } \\
\text { Markedly decreased } \\
++ \text { to }++++\end{array}$ & $\begin{array}{l}\text { Mild to moderately decreased }(20-70 \% \text { of normal }) \\
\text { Negative } \\
\text { Increased } \\
\text { Markedly decreased } \\
\text { None to }+++\end{array}$ \\
\hline $\begin{array}{l}\text { Therapeutic response to } \\
\text { TPE } \\
\text { Platelet transfusion } \\
\text { rADAMTS13 }\end{array}$ & $\begin{array}{l}\text { Very good response } \\
\text { Contraindicated } \\
\text { Unknown at this time; expected to be effective in hereditary } \\
\text { TTP }\end{array}$ & $\begin{array}{l}\text { Excellent and fast response if treated in early stage } \\
\text { Contraindicated } \\
\text { Unknown at this time; expected to be very effective }\end{array}$ \\
\hline
\end{tabular}


Table 3. Hematological and Clinical Characteristics of endotheliopathy-associated DIT and true DIC.

\begin{tabular}{|c|c|c|}
\hline & Endotheliopathy-associated DIT (including "DIC" of McKay) & True DIC \\
\hline Examples & TTP-like syndrome & DIC associated with APL \\
\hline Nature of the disorder & Microthrombosis made of platelet-ULVWF complexes & Coagulation activated by TF-FVIIa complexes \\
\hline Mechanism of the genesis & Intravascular microthrombogenesis & Intravascular coagulation \\
\hline Inciting events & $\begin{array}{l}\text { Sepsis, complications of surgery, pregnancy, cancer, } \\
\text { and transplant, and drugs/toxins leading to endotheliopathy }\end{array}$ & APL and drugs (?) leading to TF expression \\
\hline Hematological manifestations & TTP-like syndrome & Hemorrhagic disorder of APL \\
\hline $\begin{array}{l}\text { Pathogenesis } \\
\text { Mechanism } \\
\text { Site of activation } \\
\text { Pathology } \\
\text { Result of pathogenesis }\end{array}$ & $\begin{array}{l}\text { Activation of microthrombotic pathway } \\
\text { Intravascular membrane of the endothelium } \\
\text { Endothelial activation/dysfunction } \rightarrow \text { endotheliopathy } \\
\text { Formation of platelet-ULVWF microthrombi }\end{array}$ & $\begin{array}{l}\text { Activation of TF-FVIIa complex pathway } \\
\text { In circulation of the Intravascular space } \\
\text { TF expression } \rightarrow \text { coagulation and factor consumption } \\
\text { Depletion of fibrinogen, FVIII, FV }\end{array}$ \\
\hline Essence of pathology & Arteriolar and capillary luminal hyaline microthrombi & Incoagulable blood/unstable blood clots \\
\hline Effect on the involved organs & Vascular microthrombosis leading to organ hypoxia & Hemorrhage leading to organ damage \\
\hline $\begin{array}{l}\text { Coagulation tests } \\
\text { Fibrinogen } \\
\text { PT; aPTT; TT } \\
\text { FDP } \\
\text { FVIII activity } \\
\text { Thrombocytopenia }\end{array}$ & $\begin{array}{l}\text { Normal } \\
\text { Prolonged } \\
\text { Normal } \\
\text { Normal or markedly increased } \\
\text { Moderately severe }\end{array}$ & $\begin{array}{l}\text { Decreased } \\
\text { Prolonged } \\
\text { Increased } \\
\text { Markedly decreased } \\
\text { Mild to very severe }\end{array}$ \\
\hline Associated clinical syndromes & $\begin{array}{l}\text { TTP-like syndrome } \\
\text { TMA } \\
\text { MODS } \\
\text { SIRS }\end{array}$ & Hemorrhagic disorder \\
\hline $\begin{array}{l}\text { Associated hematologic features } \\
\text { Schistocytes } \\
\text { MAHA/aMAHA } \\
\text { Consumptive thrombocytopenia } \\
\text { Hepatic coagulopathy }\end{array}$ & $\begin{array}{l}0-+++ \\
\text { Often present } \\
\text { Always present } \\
\text { May occur }\end{array}$ & $\begin{array}{l}0-+(?) \\
\text { Absent } \\
\text { Present (?) } \\
\text { Unusual }\end{array}$ \\
\hline Incidence in clinical practice & Very common & Extremely rare \\
\hline $\begin{array}{l}\text { Therapy } \\
\text { Platelet transfusion } \\
\text { Treatment }\end{array}$ & $\begin{array}{l}\text { Contraindicated } \\
\text { TPE; rADAMTS13 (expected to be very effective) }\end{array}$ & $\begin{array}{l}\text { May be needed for APL } \\
\text { Treat underlying pathology (e.g., ATRA in APL) }\end{array}$ \\
\hline
\end{tabular}

"DIC" [54]. In most cases the diagnosis is based on the combination of results of non-specific abnormal coagulation profile in the patient with clinical conditions known to be associated with "DIC" [55].

In clinical medicine, "DIC" mainly has been diagnosed on clinical pretense and is accepted based on the scoring system of the International Society on Thrombosis and Haemostasis (ISTH). Because of the misconception of "DIC", DIT in the critically ill patient has been diagnosed as "DIC". "DIC" diagnosis has not been based on more reliable coagulation factor assay of FVIII and FV, which are typically depleted in true DIC [40,56-59] as seen in acute promyelocytic leukemia. In many patients with "DIC", the coagulation profile is perfectly normal and hemorrhagic tendency does not occur. Puzzled but conveniently, the concept of "chronic/compensated/ covert" was introduced. This description, however, cannot explain inexplicably extensive microthrombi in the absence of depleted coagulation factors.

"DIC" and endotheliopathy-associated DIT/VMTD (i.e., TTP-like syndrome) are exactly the same in their underlying risk factors and presentation. Both almost always occur in critical illnesses (e.g. sepsis/ septic shock, trauma, immunologic and collagen-vascular diseases, and complications of surgery, pregnancy and transplant) [38,60,61]. Pathologically both are characterized by arteriolar and capillary hyaline microthrombi with variable fibroblastic proliferation $[49,62]$. Hematologically they also present with TCIP and MAHA/aMAHA. Therefore, "DIC" and DIT are exactly the same disorder.

\section{“DIC" perplexity explained}

Considering the different pathogenic mechanisms between DIC and DIT, "DIC" must have been started with a incorrect concept. Hence, "DIC" is a misnomer. For more than 60 years, this unfortunate misconception on "DIC" has created confusion in medical science and practice, including diagnostic dilemma [54,55] and treatment failures to date [63].

If one accepts the fact that "DIC" is a misnomer and its euonym must be endotheliopathy-associated DIT, "DIC" can be explained perfectly well by the concept of DIT. The only remaining question is how "DIC" sometimes is associated with hemorrhagic disorder. Another word, "What is the correct diagnosis for acute "DIC" that is associated with abnormal coagulation profile?" The hemorrhagic disorder in "DIC" can be explained by hepatic vascular microthrombosis. Endotheliopathyassociated DIT/VMTD can trigger acute hepatic necrosis syndrome leading to hepatic coagulopathy [40]. Indeed, hepatic coagulopathy shows exactly the same coagulation profile as seen in "acute DIC".

True DIC is very rare but perhaps occurs in acute promyelocytic leukemia, presumably due to TF expression from leukemic cells [64]. The predominant feature of true DIC is hemorrhagic disorder without MAHA/aMAHA, hypoxic organ dysfunction and MODS [56-58]. In differentiating true DIC from hepatic coagulopathy, the appropriate test is the assay of coagulation factors, especially FVIII and FV, which are depleted in true DIC. More importantly, in hepatic coagulopathy, FVIII is normal or increased although it is markedly decreased in true DIC $[40,58,59]$. Also, a markedly decreased liver dependent FVII occurs in hepatic coagulopathy. A suggested guideline for laboratory tests is presented in Table 4 to aid the differential diagnosis among complicated thrombopathies and coagulopathies [36].

\section{Conclusion}

In the critically ill patient, TCIP is the earliest sign suggestive of microthrombogenesis in progress. In addition to inflammation, 
Table 4. Differential characteristic hematologic features among thrombopathies and coagulopathies (Adapted and modified from Chang JC (36) with permission).

\begin{tabular}{|c|c|c|c|c|}
\hline & TTP \& TTP-like syndrome (DIT) & $\begin{array}{l}\text { TTP-like syndrome (DIT) } \\
\text { associated with HC (e.g., Ebola) }= \\
\text { acute "DIC" }\end{array}$ & $\begin{array}{l}\text { DIC (e.g., acute promyelocytic } \\
\text { leukemia) }\end{array}$ & PF (e.g., amyloidosis) \\
\hline Thrombocytopenia & Always present & Always present & Always present & Not present \\
\hline MAHA/aMAHA & Almost always present & Usually present & Very unlikely to be present & Not present \\
\hline Fibrinogen & Normal & Decreased & Always decreased & Always decreased \\
\hline Factor VIII & Normal & Normal or increased & Markedly decreased & Decreased \\
\hline Factor V & Normal & Decreased & Decreased & Decreased (?) \\
\hline Factor X & Normal & Decreased & Usually normal & Normal \\
\hline Factor VII & Normal & Markedly decreased & Normal & Normal \\
\hline Factor IX & Normal & Decreased & Normal & Normal \\
\hline FDP & Normal & Positive & Positive & Strongly positive \\
\hline Thrombin time & Normal & Prolonged & Prolonged & Prolonged \\
\hline Thrombosis form & Microthrombi & Microthrombi & $\begin{array}{l}\text { Friable macrothrombi (?) or not } \\
\text { formed }\end{array}$ & Absent \\
\hline Bleeding: Character & Rare, mild petechiae & May cause serious bleeding & Common, serious bleeding & Slow \& persistent bleeding \\
\hline Treatment & Usually no need of treatment & Controllable with FFP & $\begin{array}{l}\text { Abrogated with ATRA \& } \\
\text { chemotherapy }\end{array}$ & Treatable with AFA \\
\hline Platelet transfusion & Contraindicated & Contraindicated & May be used with ATRA & Not needed \\
\hline
\end{tabular}

endotheliopathy-associated DIT/VMTD may lead to MODS, TMA, TTP-like syndrome and SIRS. "DIC" presents with the same clinical, pathologic and hematologic features as TTP-like syndrome. "DIC" should be correctly renamed as TTP-like syndrome.

\section{Author disclosures}

The author Jae C. Chang, M.D. has neither actual nor potential conflicts of interest in regard to this article. The author has no connection to or personal interest in any company.

\section{References}

1. Thachil J, Warkentin TE (2017) How do we approach thrombocytopenia in critically ill patients? Br J Haematol 177: 27-38. [Crossref]

2. Tsirigotis P, Chondropoulos S, Frantzeskaki F, Stamouli M, Gkirkas K, et al. (2016) Thrombocytopenia in critically ill patients with severe sepsis/septic shock: Prognostic value and association with a distinct serum cytokine profile. J Crit Care 32: 9-15. [Crossref]

3. Zhang S, Cui YL, Diao MY, Chen DC, Lin ZF1 (2015) Use of platelet indices for determining illness severity and predicting prognosis in critically Ill patients. Chin Med $J$ (Engl) 128: 2012-2018. [Crossref]

4. Nguyen TC, Carcillo JA (2006) Bench-to-bedside review: thrombocytopeniaassociated multiple organ failure--a newly appreciated syndrome in the critically ill. Crit Care 10: 235. [Crossref]

5. Greinacher A, Selleng S (2016) How I evaluate and treat thrombocytopenia in the intensive care unit patient. Blood 128: 3032-3042. [Crossref]

6. Katz JN, Kolappa KP, Becker RC (2011) Beyond thrombosis: the versatile platelet in critical illness. Chest 139: 658-668. [Crossref]

7. Moreau D, Timsit JF, Vesin A, Garrouste-Orgeas M, de Lassence A, et al. (2007) Platelet count decline: an early prognostic marker in critically ill patients with prolonged ICU stays. Chest 131: 1735-1741. [Crossref]

8. Akca S, Haji-Michael P, de Mendonça A, Suter P, Levi M, et al. (2002) Time course of platelet counts in critically ill patients. Crit Care Med 30: 753-756. [Crossref]

9. Krishnan J, Morrison W, Simone S, Ackerman A (2008) Implications of thrombocytopenia and platelet course on pediatric intensive care unit outcomes. Pediatr Crit Care Med 9: 502-505. [Crossref]

10. Thiele T, Selleng K, Selleng S, Greinacher A, Bakchoul T (2013) Thrombocytopenia in the intensive care unit-diagnostic approach and management. Semin Hematol 50: 239-250. [Crossref]

11. Stravitz RT, Ellerbe C, Durkalski V, Reuben A, Lisman T, Lee WM (2016) Acute liver failure study group. Thromobcytopenia is associated with multi-organ system failure in patients with acute liver failure. Clin Gastroenterol Hepatol 14: 613-620. [Crossref]
12. Nydam TL, Kashuk JL, Moore EE, Johnson JL, Burlew CC, et al. (2011) Refractory postinjury thrombocytopenia is associated with multiple organ failure and adverse outcomes. J Trauma 70: 401-406. [Crossref]

13. Tang DM, Zhang HJ, Jing BW, Chen DC (2003) Analysis of platelets in the monitoring of systemic inflammatory response syndrome of critically ill patients. Zhongguo Wei Zhong Bing Ji Jiu Yi Xue 15: 35-37. [Crossref]

14. Ogura H, Gando S, Iba T, Eguchi Y, Ohtomo Y, et al. (2007) SIRS-associated coagulopathy and organ dysfunction in critically ill patients with thrombocytopenia. Shock 28: 411-417. [Crossref]

15. Mackman N (2009) The role of tissue factor and factor VIIa in hemostasis. Anesth Analg 108: 1447-1452. [Crossref]

16. Aird WC (2003) The role of the endothelium in severe sepsis and multiple organ dysfunction syndrome. Blood 101: 3765-3777. [Crossref]

17. Srikiatkhachorn A, Spiropoulou CF (2014) Vascular events in viral hemorrhagic fevers: a comparative study of dengue and hantaviruses. Cell Tissue Res 355: 621-633. [Crossref]

18. Xing K, Murthy S, Liles WC, Singh JM (2012) Clinical utility of biomarkers of endothelial activation in sepsis--a systematic review. Crit Care 16: R7. [Crossref]

19. Calfee CS, Eisner MD, Ware LB, Thompson BT, Parsons PE, et al. (2007) Traumaassociated lung injury differs clinically and biologically from acute lung injury due to other clinical disorders. Crit Care Med 35: 2243-2250. [Crossref]

20. Dobson GP (2015) Addressing the global burden of trauma in major surgery. Front Surg 2: 43. [Crossref]

21. Powe CE, Levine RJ, Karumanchi SA (2011) Preeclampsia, a disease of the materna endothelium: the role of antiangiogenic factors and implications for later cardiovascular disease. Circulation 123: 2856-2869. [Crossref]

22. Maniatis NA, Kotanidou A, Catravas JD, Orfanos SE (2008) Endothelial pathomechanisms in acute lung injury. Vascul Pharmacol 49: 119-133. [Crossref]

23. Zhang C (2008) The role of inflammatory cytokines in endothelial dysfunction. Basic Res Cardiol 103: 398-406. [Crossref]

24. Janicek MJ, Van den Abbeele AD, Hollenberg NK, Kassis AI, Holman BL, Tumeh SS (1990) Platelet activation and aggregation after endothelial injury. Assessment with indium-111-labeled platelets and angiography. Invest Radiol 25: 988-993. [Crossref]

25. van Hinsbergh VW (2012) Endothelium--role in regulation of coagulation and inflammation. Semin Immunopathol 34: 93-106. [Crossref]

26. Bockmeyer CL, Claus RA, Budde U, Kentouche K, Schneppenheim R, et al. (2008) Inflammation-associated ADAMTS13 deficiency promotes formation of ultra-large von Willebrand factor. Haematologica 93: 137-140. [Crossref]

27. Valentijn KM, van Driel LF, Mourik MJ, Hendriks GJ, Arends TJ, et al. (2010) Multigranular exocytosis of Weibel-Palade bodies in vascular endothelial cells. Blood 116: 1807-1816. [Crossref] 
28. Turner NA, Moake J (2013) Assembly and activation of alternative complement components on endothelial cell-anchored ultra-large von Willebrand factor links complement and hemostasis-thrombosis. PLoS One 8: e59372. [Crossref]

29. Moake JL (2004) von Willebrand factor, ADAMTS-13, and thrombotic thrombocytopenic purpura. Semin Hematol 41: 4-14. [Crossref]

30. Levi M, Schultz M, van der Poll T (2013) Sepsis and thrombosis. Semin Thromb Hemost 39: 559-566. [Crossref]

31. Erez O, Mastrolia SA, Thachil J (2015) Disseminated intravascular coagulation in pregnancy: insights in pathophysiology, diagnosis and management. Am J Obstet Gynecol 213: 452-463. [Crossref]

32. Lippi G, Cervellin G (2010) Disseminated intravascular coagulation in trauma injuries. Semin Thromb Hemost 36: 378-387. [Crossref]

33. Chang JC, Shipstone A, Llenado-Lee MA (1996) Postoperative thrombotic thrombocytopenic purpura following cardiovascular surgeries. Am J Hematol 53: 1117. [Crossref]

34. Chang JC (2004) The understanding of thrombotic thrombocytopenic purpura: Dyadic, triadic, pentadic, and other manifestations. J Clin Apher 19: 2-4. [Crossref]

35. Chang JC, Aly ES (2001) Acute respiratory distress syndrome as a major clinical manifestation of thrombotic thrombocytopenic purpura. Am J Med Sci 321: 124-128. [Crossref]

36. Chang JC (2016) A thought on possible pathogenesis of ebola viral hemorrhagic disease and potential treatments: Could it be thrombotic thrombocytopenic purpuralike syndrome? J Ther Aph Dialysis 20: 93-98. [Crossref]

37. Goldberg RJ, Nakagawa T, Johnson RJ, Thurman JM (2010) The role of endothelial cell injury in thrombotic microangiopathy. Am J Kidney Dis 56: 1168-1174. [Crossref]

38. Booth KK, Terrell DR, Vesely SK, George JN (2011) Systemic infections mimicking thrombotic thrombocytopenic purpura. Am J Hematol 86: 743-751. [Crossref]

39. Chang JC, Newman RS (2004) Redefining the syndromes of thrombotic microangiopathy. Ther Apher Dial 8: 73-74. [Crossref]

40. Chang JC (2017) Viral hemorrhagic fevers due to endotheliopathy-associated disseminated inrtravascular microthrombosis and hepatic coagulopathy: pathogenesis based on "two-activation theory of the endothelium". Clin Micro Infec Dis.

41. Esmon CT (2005) The interactions between inflammation and coagulation. $B r J$ Haematol 131: 417-430. [Crossref]

42. Levi M, van der Poll T (2010) Inflammation and coagulation. Crit Care Med 38: S2634. [Crossref]

43. Langer HF, Chavakis T (2009) Leukocyte-endothelial interactions in inflammation. $J$ Cell Mol Med 13: 1211-1220. [Crossref]

44. Barreiro O, Sánchez-Madrid F (2009) Molecular basis of leukocyte-endothelium interactions during the inflammatory response. Rev Esp Cardiol 62: 552-562. [Crossref]

45. Balk RA (2014) Systemic inflammatory response syndrome (SIRS): where did it come from and is it still relevant today? Virulence 5: 20-26. [Crossref]

46. De Ceunynck K, De Meyer SF, Vanhoorelbeke K (2013) Unwinding the von Willebrand factor strings puzzle. Blood 121: 270-277. [Crossref]
47. Padilla A, Moake JL, Bernardo A, Ball C, Wang Y, et al. (2004) P-selectin anchors newly released ultralarge von Willebrand factor multimers to the endothelial cell surface. Blood 103: 2150-2156. [Crossref]

48. Zheng XL (2015) ADAMTS13 and von Willebrand factor in thrombotic thrombocytopenic purpura. Annu Rev Med 66: 211-225. [Crossref]

49. Tsai HM (2010) Pathophysiology of thrombotic thrombocytopenic purpura. Int $J$ Hematol 91: 1-19. [Crossref]

50. McKay DG, Margaretten W (1967) Disseminated intravascular coagulation in virus diseases. Arch Intern Med 120: 129-152. [Crossref]

51. Sundberg E, Hultdin J, Nilsson S, Ahlm C (2011) Evidence of disseminated intravascular coagulation in a hemorrhagic fever with renal syndrome-scoring models and severe illness. PLoS One 6: e21134. [Crossref]

52. Hunt BJ (2014) Bleeding and coagulopathies in critical care. N Engl J Med 370: 847859. [Crossref]

53. Levi M, Opal SM (2006) Coagulation abnormalities in critically ill patients. Crit Care 10: 222. [Crossref]

54. Slofstra SH, Spek CA, ten Cate H (2003) Disseminated intravascular coagulation Hematol J 4: 295-302. [Crossref]

55. Franchini M, Lippi G, Manzato F (2006) Recent acquisitions in the pathophysiology, diagnosis and treatment of disseminated intravascular coagulation. Thromb $J$ 4: 4. [Crossref]

56. Cooperberg AA (1967) Acute promyelocytic leukemia. Can Med Assoc J 97: 57-63. [Crossref]

57. Chang JC, Gross HM, Jang NS (1990) Disseminated intravascular coagulation due to intravenous administration of hetastarch. Am J Med Sci 300: 301-303. [Crossref]

58. Senzolo M, Burra P, Cholongitas E, Burroughs AK (2006) New insights into the coagulopathy of liver disease and liver transplantation. World J Gastroenterol 12: 7725-7736. [Crossref]

59. Castellone D. http://www.aniara.com/Blog/Coagulation-Corner/archives/2010/11/ LIVER-DISEASE-AND-COAGULATION-OUTCOMES.aspx

60. Franchini M1, Lippi G, Manzato F (2006) Recent acquisitions in the pathophysiology, diagnosis and treatment of disseminated intravascular coagulation. Thromb $J$ 4: 4 [Crossref]

61. Nguyen TC, Kiss JE, Goldman JR, Carcillo JA (2012) The role of plasmapheresis in critical illness. Crit Care Clin 28: 453-468. [Crossref]

62. Sueishi K, Takeuchi M (1993) Pathology of disseminated intravascular coagulation. Nihon Rinsho 51: 30-36.

63. Marshall JC (2014) Why have clinical trials in sepsis failed? Trends Mol Med 20: 195 203. [Crossref]

64. Tallman MS, Hakimian D, Kwaan HC, Rickles FR (1993) New insights into the pathogenesis of coagulation dysfunction in acute promyelocytic leukemia. Leuk Lymphoma 11: 27-36. [Crossref]

Copyright: (C)2017 Chang JC. This is an open-access article distributed under the terms of the Creative Commons Attribution License, which permits unrestricted use, distribution, and reproduction in any medium, provided the original author and source are credited. 